\title{
The syringes catastrophe of the HIV outbreak in Faisalabad, Punjab, Pakistan
}

\author{
Amreen Zahra1 ${ }^{1}$ Muhammad Naveed*,1, Irfan Ahmad², Mushtaq A Saleem ${ }^{1}$ \& Basit Zeshan ${ }^{3}$ \\ ${ }^{1}$ Department of Biochemistry \& Biotechnology, Faculty of Life Sciences, University of Central Punjab, Lahore, 54700, Pakistan \\ ${ }^{2}$ Institute of Biomedical \& Allied Health Sciences, University of Health Sciences, Lahore, 54000, Pakistan \\ ${ }^{3}$ Department of Microbiology, Faculty of Life Sciences, University of Central Punjab, Lahore, 54700, Pakistan \\ *Author for correspondence: Tel.: 0092 3015524624; naveed.quaidian@gmail.com
} "'Recently as per reports of June in Pakistan, UNAIDS and National AIDS Control Programme stated
around 24,331 people (14.7\%) are registered with the National AIDS Control Program for HIV."

First draft submitted: 16 July 2019; Accepted for publication: 11 September 2019; Published online: 16 October 2019

Keywords: antiretroviral therapy • epidemics • HIV outbreak • infectious disease $\bullet$ UNAIDS• WHO

In recent years, the deadly catastrophes of HIV outbreaks in different areas have jolted the nation [1]. Pakistan is still working and fighting to combat this deadly disease which has now turned to an uncontrollable epidemic. Recently as per reports of June in Pakistan, UNAIDS and National AIDS Control Programme stated around 24,331 people (14.7\%) are registered with the National AIDS Control Program for HIV. Among these HIVpositive patients, only $17,149(70.5 \%)$ of the registered patients were receiving antiretroviral therapy, and 7182 (29.5\%) did not follow-up proper appointments in the last 6 months [2].

On 25 April 2019, a small town of Larkana named Ratodero, faced the worst outbreak of history with around 13 new cases of HIV-positive children, aged between 1 and 5 years, increasing the total infected number to 812, of which 661 were children diagnosed in a time span of 2 months [3,4]. While the Nation was coping with this deadly ordeal, 2863 new cases of HIV were registered in Faisalabad, Punjab, Pakistan on 12 June 2019 [5]. Most of the diagnosed patients were drug addicts and had acquired HIV through reused syringes and needles, treatment by local fraudulent healthcare providers, also known as 'quacks' and dental surgeries with improper sanitation. The patients hailed mainly from nearby cities such as Chiniot, Sahiwal, Jhang, and Nankana Sahib in Punjab [6]. Although the estimated burden of HIV in Pakistan was not so high previously, as it was identified as a low-prevalence country for the spread of HIV infection. At the end of 2000, the prevalence of infection rose and the increasing number of cases in recent years has brought alarming concern for public health and safety to the national healthcare authorities [7]. The trend has, therefore, shifted from low to high rising HIV infection, in the country. Recently WHO declared the HIV outbreak as a grade II emergency in Pakistan [8]. International expert teams from WHO and CDC Atlanta reported that malpractices of unsafe injections, reuse of needles, intravenous drips and negligent infection control at healthcare centers, was one of the leading causes of the havoc. This was not limited to a single province as this malpractice is widespread throughout the nation and if not controlled quickly, will lead to further outbreaks across the country [9].

In March 2018, in Kot Momin, a village near Sargodha, many patients were diagnosed with HIV which alerted the provincial AIDS control authorities in Punjab. The use of contaminated syringes and needles by a local untrained health personnel, who later died of AIDS himself, infected a high proportion of rural populations in two villages and intensified the spread of the fatal disease, with a massive outbreak of HIV occurring $[10,11]$. Contaminated blood products, unchecked blood transfusions, ear and nose piercings, unsterilized surgical and dental instruments, razor sharing by local barbers have also contributed to the spread and transmission over time [12,13]. The Pakistan Medical Association reported that around 600,000 quacks are currently practicing in the country among which 80,000 are based in Punjab alone [14]. Social taboos and stigmas associated with HIV are also major risk factors preventing its eradication in a socially conservative society like Pakistan and many other similar underdeveloped countries. The National AIDS Control Program of the Government must take immediate action against quacks and develop 
novel strategies to overcome this health emergency. Increased access to screening, treatment and counseling at the national level is vital for prevention and elimination of AIDS and must be a priority to save the future generations from such fatal viral infections.

\section{Author contributions}

A Zahra conceived, and wrote the editorial, M Naveed, I Ahmad and MA Saleem proofread the study and confirmed the data and sources.

\section{Financial \& competing interests disclosure}

The authors have no relevant affiliations or financial involvement with any organization or entity with a financial interest in or financial conflict with the subject matter or materials discussed in the manuscript. This includes employment, consultancies, honoraria, stock ownership or options, expert testimony, grants or patents received or pending, or royalties.

No writing assistance was utilized in the production of this manuscript.

\section{References}

1. National AIDS Control Programme. National Institute of Health Islamabad. www.nih.org.pk/national-aids-control-programme/

2. Pakistan National AIDS Control Programme. www.nacp.gov.pk/index.html

3. The Nation. 13 children diagnosed with AIDS in Larkana

(2019). https://nation.com.pk/26-Apr-2019/13-children-diagnosed-with-aids-in-larkana

4. Pakistan Today. 812 HIV positive cases found in Ratodero till date (2019). www.pakistantoday.com.pk/2019/06/18/812-hiv-positive-cases-found-in-ratodero-till-date/

5. Abb Tak. Major outbreak of HIV positive cases reported in Faisalabad (2019). https://abbtakk.tv/en/major-outbreak-of-hiv-positive-cases-reported-in-faisalabad

6. Dawn. Alarming surge in HIV/AIDS cases in five districts of Punjab (2019). www.dawn.com/news/1487667

7. UNAIDS. Pakistan. www.unaids.org/en/regionscountries/countries/pakistan

8. The News. WHO declares HIV outbreak in Larkana as Grade 2 emergency (2019). www.thenews.com.pk/latest/481688-who-declares-hiv-outbreak-in-larkana-as-grade-2-emergency

9. The Wall Street Journal. Reused syringes, drips infected hundreds of Pakistani children with HIV (2019). www.wsj.com/articles/reusing-syringes-drips-infected-hundreds-of-pakistani-children-with-hiv- 11560503649

10. Zaid M, Afzal MS. HIV outbreak in Pakistan. Lancet Infect. Dis. 18(6), 601 (2018).

11. Wahid B. An update on the severe outbreak of HIV in Kot Imrana, Pakistan. Lancet Infect. Dis. 19(3), 241 (2019).

12. Bergenstrom A, Achakzai B, Furqan S et al. Drugs-related HIV epidemic in Pakistan: a review of current situation and response and the way forward beyond 2015. Harm. Reduct. J. 12, 43 (2015).

13. Waheed Y, Shafi T, Safi Sher Z et al. Hepatitis $\mathrm{C}$ virus in Pakistan: a systematic review of prevalence, genotypes and risk factors. World J. Gastroenterol. 15(4), 5647-5653 (2009).

14. Gulf News. Pakistani doctors blame quacks for alarming rise in HIV cases

(2019). https:/gulf news.com/world/asia/pakistan/pakistani-doctors-blame-quacks-for-alarming-rise-in-hiv-cases-1.64559791 